\title{
PENGARUH METODE PEMBELAJARAN KOOPERATIF DAN GAYA KOGNITIF TERHADAP HASIL BELAJAR ILMU SOSIAL (Studi Eksperimental di Kelas IV SD 02 Muktiwari Cibitung Kabupaten Bekasi Tahun 2014/2015)
}

\section{Yayan Alpian}

Program Studi Pendidikan Dasar PPS UNJ zalma.biaza@yahoo.com

\begin{tabular}{ll}
\hline $\begin{array}{l}\text { Informasi artikel } \\
\text { Sejarah artikel }\end{array}$ & \\
Diterima & $: 28 / 10$ \\
Revisi & $: 16$ \\
Dipublikasikan & $: 28 / 12 / 2107$
\end{tabular}

\section{Kata kunci:}

metode pembelajaran kooperatif, gaya kognitif,

hasil belajar ilmu sosial

\begin{abstract}
ABSTRAK
Gaya kognitif (Field Independent dan Field Dependent) yang dimiliki oleh individu menjadi salah satu faktor internal mendukung penciptaan hasil belajar yang maksimal. Penelitian ini bertujuan untuk mengetahui pengaruh teknik metode pembelajaran kooperatif make a match dan think pair share terhadap hasil belajar kognitif siswa pada Ilmu Sosial.

Penelitian ini merupakan rancangan penelitian eksperimental dengan menggunakan Desain dengan level $2 \times 2$ dengan deret double variance test (ANOVA 2x2). Populasi dalam penelitian ini adalah seluruh siswa SDN Muktiwari 02 Kecamatan Cibitung Kabupaten Bekasi tahun ajaran 2014/2015. Teknik pengambilan sampel dalam penelitian dengan cara teknik random sampling. Teknik analisis data menggunakan ANAVA dua jalur dan pengujian simple effect dengan Uji Tuckey.

Hasil penelitian menyebutkan bahwa terdapat pengaruh yang signifikan antara interaksi antara metode pembelajaran cooperative (teknik Make a match dan teknik Think Pair Share) dengan gaya kognitif dan berpengaruh terhadap tinggi rendahnya hasil belajar IPS siswa kelas IV Sekolah Dasar.
\end{abstract}

ABSTRACT
The cognitive style (Field Independent and Field Dependent) possessed by
the individual becomes one of the internal factors supporting the creation
of maximum learning outcomes. This study aims to know the effect of
cooperative learning methods techniques make a match and think pair
share techniques and cognitive style students' learning outcomes Social
Sciences.
This research is experimental research design using Design by level 2 x 2
with a double row of Variance test (ANOVA $2 \times 2$ ). Population in this
research is all student of SDN Muktiwari O2 District of Cibitung Regency
of Bekasi academic year $2014 / 20 I 5$. samples were taken using random
sampling technique. Data analysis techniques use two-way ANAVA and
simple effect test with Tuckey Test.
The results showed that there is an interaction effect between cooperative
learning method (Make a match techniques and techniques Think Pair
Share) and cognitive style on Social Sciences student learning outcomes
cooperative learning methods techniques make a match and think pair share techniques and cognitive style students' learning outcomes Social Sciences.

This research is experimental research design using Design by level $2 \times 2$ with a double row of Variance test (ANOVA 2 2 ). Population in this research is all student of SDN Muktiwari 02 District of Cibitung Regency of Bekasi academic year 2014/2015. samples were taken using random sampling technique. Data analysis techniques use two-way ANAVA and simple effect test with Tuckey Test.

learning method (Make a match techniques and techniques Think Pair Share) and
Key word:

cooperative learning method,

cognitive style,

social sciences learning outcomes

\section{Pendahuluan}

Manusia menurut kodratnya sebagai makhluk sosial atau makhluk bermasyarakat, manusia dikatakan sebagai makhluk sosial, karena pada dirinya ada dorongan dan kebutuhan untuk berhubungan (interaksi) dengan orang lain. Ilmu yang mempelajari interaksi manusia dengan manusia lainnya adalah 
IPS. Di jenjang persekolahan mata pelajaran IPS mempunyai tujuan untuk membentuk siswa menjadi pribadi yang mandiri dan memiliki nilai baku yang berlaku dalam masyarakat.

Susanto, A (2013: I45) mengatakan bahwa tujuan utama mata pelajaran IPS adalah untuk mengembangkan potensi siswa agar peka terhadap masalah sosial yang terjadi di masyarakat, memiliki sikap mental positif terhadap perbaikan segala ketimpangan yang terjadi, dan terampil mengatasi setiap masalah yang terjadi sehari-hari baik yang menimpa dirinya sendiri maupun yang menimpa masyarakat. Dalam pelaksanaan pembelajaran di sekolah, pembelajaran IPS dapat diintegrasikan oleh mata pelajaran lain sehingga siswa dapat mempelajari dan memaknai kehidupan dari sudut pandang manapun sehingga pembelajaran menjadi lebih bermakna. Oleh karena itu, perlu adanya keterampilan guru dalam merencanakan pembelajaran yang inovatif dan kreatif agar para siswa dapat memaknai pembelajaran IPS secara utuh dan dapat memperoleh hasil belajar yang maksimal.

Pada umumnya siswa dapat memperoleh pengetahuan sosial secara alamiah dari kehidupan sehari-hari. Namun, hal ini belum cukup mengingat kehidupan masyarakat dengan segala permasalahannya makin berkembang. Untuk menghadapi keadaan tersebut, pengetahuan sosial diperoleh secara alamiah tidak cukup. Di sini perlu pendidikan formal, khususnya pendidikan IPS. Banks yang dikutip oleh Susanto A (20I3: I4I) mengungkapkan bahwa pendidikan IPS atau yang disebut sosial studies, merupakan bagian dari kurikulum di sekolah yang bertujuan untuk membantu mendewasakan siswa supaya dapat mengembangkan pengetahuan, keterampilan, sikap, dan nilai-nilai dalam rangka berpartisipasi di dalam masyarakat, negara, dan bahkan di dunia. Banks menekankan begitu pentingnya pendidikan IPS diterapkan di sekolah-sekolah, mulai dari SD sampai ke perguruan tinggi, terutama di SD dan menengah.

Dalam menciptakan hasil belajar yang maksimal, terdapat pengaruh internal dan eksternal yang terdapat dalam diri siswa. Hal ini harus diketahui dan dipahami oleh setiap guru dalam menciptakan atmosfer pembelajaran yang dapat menciptakan lingkungan yang kondusif untuk belajar. Sementara itu, faktor internal siswa yang meliputi: faktor kesehatan, cacat tubuh, intelegensi, perhatian, motif, minat, kemampuan, kematangan, kesiapan, kelelahan, bakat, motivasi intrinsik (dari dalam diri siswa), termasuk di dalamnya gaya kognitif (Field Independent dan Field Dependent) yang dimiliki oleh individu dari masing-masing siswa. Siswa dengan kategori Field Independent memiliki kecenderungan dalam bersikap dan berperilaku yang konsisten pada dirinya dalam berpikir kritis, analitis, impersonal, memiliki motivasi yang tinggi, serta memiliki kemampuan dalam memecahkan masalah. Sementara siswa dengan Field Dependent berpikir secara global, memiliki motivasi ekstrinsik, bersifat sosial, memiliki kemampuan memecahkan masalah yang rendah. Sedangkan faktor lain yang mempengaruhi dalam proses pembelajaran adalah faktor eksternal yakni hal-hal dari luar diri siswa misalnya penerapan metode, teknik dan strategi pembelajaran yang digunakan oleh guru yang di dalamnya terdapat penggunaan media pembelajaran, termasuk kondisi lingkungan dimana siswa berada.

Salah datu faktor internal yang dapat mempengaruhi hasil belajar ialah gaya kognitif yang dimiliki oleh siswa. Keefe (1987: 7) mengungkapkan bahwa gaya kognitif merupakan bagian gaya belajar yang menggambarkan kebiasaan berprilaku yang tetap dalam diri seseorang dalam menerima, memikirkan, memecahkan masalah maupun dalam menyimpan informasi. Selanjutnya Woolfolk yang dikutip oleh Desmita (2009: I44) mengatakan bahwa di dalam gaya kognitif terdapat suatu cara yang berbeda untuk melihat, mengenal, dan mengorganisir informasi. Setiap individu akan memilih cara yang lebih disukai dalam memproses dan mengorganisasi informasi sebagai respon terhadap stimuli lingkungannya. Kemungkinan ada individu yang memberikan respons lebih cepat, tetapi ada pula yang lebih lambat. Cara-cara memberi respon terhadap stimuli ini berkaitan erat dengan sikap dan kualitas personal. Gaya kognitif merupakan pola yang terbentuk dari cara individu memproses informasi, yang cenderung stabil dan dicapai dalam jangka waktu yang cukup lama, meskipun ada kemungkinan untuk berubah. 
Cara yang berbeda untuk melihat, mengenal, dan mengorganisir informasi pada gaya kognitif dibagi menjadi dua yaitu Field Dependent dan Field Independent. Menurut Brown, D (2008: I30) siswa yang memiliki karakteristik gaya kognitif Field Dependent lebih condong bersosialisasi, menyatukan diri dengan orang-orang di sekitar mereka, dan biasanya lebih berempati dan memahami perasaan dan pemikiran orang lain. Sedangkan menurut Slameto (20I0: I6I) siswa yang memiliki gaya kognitif Field Independent cenderung menyatakan suatu gambaran lepas dan latar belakang gambaran tersebut, serta mampu membedakan objek-objek dari konteks sekitarnya dengan lebih mudah. Umumnya mereka mampu dengan mudah menghadapi tugas-tugas yang memerlukan perbedaan-perbedaan dan analisis.

Berdasarkan hasil observasi pada proses pembelajaran IPS di SDN Muktiwari 02 masih terdapat kelemahan dalam proses pembelajaran yakni guru tidak memanfaatkan kemampuan berpikir siswa secara maksimal. Hal ini, dikarenakan guru masih menggunakan pembelajaran konvensional yang tidak dapat menunjukkan aspek kompetitif pada diri siswa dan hanya dapat menghasilkan sifat individualistik. Pada pembelajaran konvensional, guru menjadi pusat pembelajaran yang berperan mentransfer dan meneruskan informasi kepada siswa sehingga siswa tidak perlu mengkontruksi ideidenya. Tingkat partisipasi siswa sangat terbatas karena arus interaksi didominasi oleh guru. Bentuk penugasan dalam pembelajaran bersifat individual. Sebagai konsekuensinya, evaluasi yang diterapkan di kelaspun juga individual. Dalam hal ini, guru seyogyanya merancang dan melaksanakan kegiatan proses pembelajaran dengan menggunakan beberapa metode pembelajaran, diantaranya metode yang dapat digunakan untuk menumbuhkan keaktifan siswa dalam pembelajaran yaitu metode cooperative learning salah satunya yaitu dengan menggunakan teknik make a match dan teknik think Pair Share (TPS). Di mana teknik pembelajaran ini menitikberatkan keaktifan siswa dalam proses pembelajaran sehingga siswa saling bekerja sama dalam menyelesaikan masalah.

Setelah seorang guru mengetahui gaya kognitif siswa dalam proses proses pemebalajarn guna mencapai hasil belajar yang diinginkan maka seyogyanya seorang guru dapat merancang suatu metode/teknik pembelajaran yang dapat menciptakan suasana pembelajaran yang menarik bagi siswa sesuai dengan karakteristik gaya kognitif yang dimilikinya. Salah satu metode pembelajaran yang dapat diterapkan oleh guru adalah metode pembelajaran berbasis kelompok atau cooperative. Sejalan dengan itu, Slavin (2005: 4) mengungkapkan bahwa pembelajaran cooperative merujuk pada berbagai macam metode pembelajaran di mana para siswa bekerja dalam kelompok-kelompok kecil untuk saling membantu satu sama lainnya dalam mempelajari materi pelajaran. Hal ini menunjukkan bahwa dalam kelas cooperative, para siswa diharapkan dapat saling membantu, saling mendiskusikan dan berargumentasi, untuk mengasah pengetahuan yang mereka kuasai saat itu dan menutup kesenjangan dalam pemahaman masing-masing. Di dalam metode cooperative ada beberpa macam teknik yang dapat digunakan oleh guru dalam proses pembelajaran di dalam kelas. Salah satunya yaitu teknik Make a match dan teknik Think pair share.

Anita Lie (2008: 56) menyatakan bahwa model pembelajaran tipe Make a match atau bertukar pasangan merupakan teknik belajar yang memberi kesempatan siswa untuk bekerja sama dengan orang lain. Teknik ini bisa digunakan dalam semua mata pelajaran dan untuk semua tingkatan usia anak didik. Menurut Suprijono, A (20I2: 94) Hal-hal yang perlu dipersiapkan jika pembelajaran dikembangkan dengan teknik make a match adalah kartu-kartu. Kartu-kartu tersebut terdiri dari kartu berisi pertanyaan-pertanyaan dan kartu-kartu lainnya berisi jawaban dari pertanyaan-pertanyaan tersebut.

Sedangkan menurut Trianto (2007: 6I) teknik think pair share (TPS) atau berpikir berpasangan berbagi adalah jenis pembelajaran cooperative yang dirancang untuk mempengaruhi pola interaksi siswa. Teknik TPS ini berkembang dari penelitian belajar cooperative dan waktu tunggu. Pertama kali dikembangkan oleh Profesor Frank Lyman di Universitas of Maryland pada tahun I98I dan diadopsi oleh banyak penulis di bidang pembelajaran cooperative pada tahun-tahun selanjutnya. Frank Lyman menyatakan bahwa think pair share merupakan suatu cara efektif untuk membuat variasi suasana pola diskusi kelas. Sedangkan menurut Hamdayana, J (20I4: 206) Think pair share merupakan suatu teknik sederhana dengan keuntungan besar. Think pair share dapat meningkatkan kemampuan siswa dalam 
mengingat suatu informasi dan seorang siswa juga dapat belajar dari siswa lain serta saling menyampaikan idenya untuk didiskusikan sebelum disampaikan di depan kelas. Selain itu, Think pair share juga dapat memperbaiki rasa percaya diri dan semua siswa diberi kesempatan untuk berpartisipasi dalam kelas. Think pair share sebagai salah satu metode pembelajaran cooperative yang terdiri atas tiga tahapan, yaitu thinking, pairing, dan sharing. Guru tidak lagi sebagai satu-satunya sumber pembelajaran (teacher oriented), tetapi justru siswa dituntut untuk dapat menemukan dan memahami konsep-konsep baru (student oriented).

Hasil penelitian Aghniyani Zakiah (2008: I53-I54) menyatakan bahwa terdapat perbedaan pengaruh gaya kognitif field independence dan field dependence terhadap pencapaian kompetensi mata pelajaran sejarah siswa yang memiliki gaya kognitif field independence terbukti memberikan pengaruh yang lebih baik daripada siswa yang memiliki gaya kognitif field dependence terhadap pencapaian kompetensi mata pelajaran sejarah. Hasil penelitian Marwah Zaitun (20I I: I24) menyatakan bahwa bahwa proses pembelajaran dengan menerapkan pembelajaran kooperatif dengan metode mencari pasangan (make a match) dapat meningkatkan hasil belajar pada mata pelajaran Pendidikan Kewarganegaraan tentang lembaga-lembaga negara pada siswa kelas VI SD Negeri Jatimakmur III Pondokgede Bekasi. Dengan peningkatan hasil belajar dari setiap siklusnya. Dengan nilai rata-rata siklus pertama 75,76, siklus kedua 77,09 dan pada siklus ketiga 77,43. Selanjutnya hasil penelitian Ana Nurhasanah (2011: I24) menyatakan bahwa proses pembelajaran dengan menerapkan pembelajaran kooperatif dengan metode Cooperative Teknik Think Pair Share dapat meningkatkan hasil belajar pada mata pelajaran IPS pada siswa kelas V SD Negeri Kramatwatu II Serang Banten. Dengan peningkatan hasil belajar dari setiap siklusnya. Dengan nilai rata-rata siklus pertama 7I,22, siklus kedua 80,48.

\section{Metode Penelitian}

Metode yang digunakan dalam penelitian ini adalah metode eksperimen dengan menggunakan desain factorial $2 \times 2$. Populasi dalam penelitian ini adalah seluruh siswa SDN Muktiwari 02 Kecamatan Cibitung Kabupaten Bekasi tahun ajaran 20I4/20I5. Dengan jumlah siswa keseluruhan 3 I3 siswa.Teknik pengambilan sampel dalam penelitian dengan cara teknik random sampling.

Berdasarkan desain penelitian yang diajukan maka dalam penelitian ini dibentuk 2 kelompok eksperimen yang masing-masing diberi perlakuan berbeda.

Tabel I Distribusi Sampel pada Setiap Kelas Menurut Perlakuan

\begin{tabular}{|l|l|l|l|}
\hline \multirow{2}{*}{ Gaya Kognitif } & \multicolumn{2}{|l|}{ Metode Cooperative } & \multirow{2}{*}{ Jumlah } \\
\cline { 2 - 4 } & $\begin{array}{l}\text { Teknik Make a } \\
\text { match }\end{array}$ & $\begin{array}{l}\text { Teknik Think Pair } \\
\text { Share }\end{array}$ & \\
\hline Field Dependent $\left(\mathrm{B}_{1}\right)$ & 8 & 8 & $\mathrm{I} 6$ \\
\hline Field Independent $\left(\mathrm{B}_{2}\right)$ & 8 & 8 & $\mathrm{I} 6$ \\
\hline Jumlah & $\mathrm{I} 6$ & $\mathrm{I} 6$ & 32 \\
\hline
\end{tabular}

Instrumen hasil belajar IPS menggunakan tes tertulis berbentuk essay berjumlah IO soal yang diujicobakan kepada siswa kelas IV di luar sampel penelitian berjumlah 33 siswa. Instrumen gaya kognitif menggunakan tes baku GEFT. Untuk instrumen gaya kognitif ini tidak dilakukan pengujian karena instrumen yang digunakan merupakan instrumen baku sehingga tidak perlu dilakukan uji validitas dan reliabilitas instrumen. Instrumen hasil belajar IPS berjumlah IO soal dan seluruh soal 
dinyatakan valid dengan reliabilitas sebesar 0,87I. Pengujian normalitas dilakukan dengan menggunakan Uji Liliefors dan uji homogenitas dengan Uji Barlett. Teknik analisis data menggunakan ANAVA dua jalur dan pengujian simple effect dengan Uji Tuckey.

\section{Hasil dan Pembahasan}

Pengujian hipotesis dalam penelitian ini menggunakan analisis varians (ANAVA) dua jalur. Analisis varians dua jalur digunakan untuk menguji pengaruh utama (main effect), pengaruh interaksi (interaction effect) dan pengaruh sederhana ( simple effect) antara metode pembelajaran cooperative dan gaya kognitif pada siswa kelas IV Sekolah Dasar.

Selanjutnya hasil perhitungan analisis varians menujukkan adanya interaksi antara metode pembelajaran cooperative (teknik Make a match dan Think Pair Share) dan gaya kognitif terhadap hasil belajar IPS siswa kelas IV Sekolah Dasar, maka dilakukan uji lanjut dengan menggunkan uji Tuckey. Hasil perhitungan yang diperoleh dirangkum pada tabel berikut ini:

Tabel. 2 Rekapitulasi Hasil Perhitungan ANAVA 2 × 2

\begin{tabular}{|c|c|c|c|c|c|c|}
\hline \multirow{2}{*}{ Sumber Varias } & \multirow{2}{*}{$\mathrm{JK}$} & \multirow{2}{*}{$\mathrm{db}$} & \multirow{2}{*}{ RJK } & \multirow{2}{*}{$F_{\text {hitung }}$} & \multicolumn{2}{|l|}{$\mathrm{F}_{\text {tabel }}$} \\
\hline & & & & & $\alpha=0,05$ & $\alpha=0,01$ \\
\hline Antar A & 94,53 & 1 & 94,53 & 5,97 & 4,20 & 7,64 \\
\hline Antar B & 148,78 & 1 & 148,78 & 9,40 & 4,20 & 7,64 \\
\hline Interaksi A x B & 1498,78 & 1 & 1498,78 & 94,65 & 4,20 & 7,64 \\
\hline Dalam (D) & 443,38 & 28 & 15,83 & - & - & \\
\hline Total $(\mathrm{T})$ & 2185,47 & 31 & - & - & - & \\
\hline
\end{tabular}

Hasil perhitungan ANAVA menunjukan bahwa, hipotesis pertama diperoleh $\mathrm{F}_{\text {hitung }}>\mathrm{F}_{\text {tabel }}=5,97>$ 4,20 pada taraf nyata $\alpha=0,05$. Artinya, terdapat perbedaan rata-rata hasil belajar IPS siswa yang signifikan antara kelompok siswa yang menggunakan pembelajaran cooperative teknik Make a match dan teknik Think Pair Share.

Hasil perhitungan ANAVA menunjukan bahwa, hipotesis kedua diperoleh $\mathrm{F}_{\text {hitung }}>\mathrm{F}_{\text {tabel }}=9,40>4,20$ pada taraf nyata $\alpha=0,05$. Artinya, demikian terdapat perbedaan rata-rata hasil belajar IPS yang signifikan antara kelompok siswa yang memiliki gaya kognitif Field Dependent dan kelompok siswa yang memiliki gaya kognitif Field Independent.

Hipotes ketiga, hasil perhitungan ANAVA diperoleh bahwa $F_{\text {hitung }}$ untuk faktor interaksi adalah lebih besar $F_{\text {hitung }}>\mathrm{F}_{\text {tabel }(0,01)}=94,65>7,64$ pada taraf $\alpha=0,0$ I $\left(F_{\text {hitung }}>F_{\text {tabel }}=87,782>7,39\right)$. Artinya bahwa terdapat pengaruh interaksi yang sangat signifikan antar faktor A (teknik pembelajaran) dan faktor B (gaya kognitif) terhadap hasil belajar IPS siswa.

Hipotesis keempat, hasil uji tuckey menunjukkan bahwa $Q_{\text {hitung }} \mathrm{A}_{1} \mathrm{~B}_{1}-\mathrm{A}_{2} \mathrm{~B}_{1}=12,22$. Dari tabel dengan $\mathrm{n}=8$ dan $\alpha=0,05$ diketahui nilai $\mathrm{Q}_{\text {tabel }}=4,53$. Karena $\mathrm{Q}_{\text {hitung }} \mathrm{A}_{\mathrm{I}} \mathrm{B}_{\mathrm{I}}-\mathrm{A}_{2} \mathrm{~B}_{\mathrm{I}}=\mathrm{I} 2,22>\mathrm{Q}_{\text {tabel }}=4,53$ atau Ho ditoak, maka hasil belajar IPS pada kelompok siswa yang belajar dengan teknik pembeajaran Make a match dan gaya kognitif Field Dependent lebih tinggi daripada siswa yang belajar dengan teknik Think pair share dan gaya kognitif Field Dependent.

Hipotesis kelima, hasil uji tuckey menunjukkan bahwa $\mathrm{Q}_{\text {hitung }} \mathrm{A}_{1} \mathrm{~B}_{2}-\mathrm{A}_{2} \mathrm{~B}_{2}=7,36$. Dari tabel dengan $\mathrm{n}=$ 8 dan $\alpha=0,05$ diketahui nilai $\mathrm{Q}_{\text {tabel }}=4,53$. Karena $\mathrm{Q}_{\text {hitung }} \mathrm{A}_{1} \mathrm{~B}_{2}-\mathrm{A}_{2} \mathrm{~B}_{2}=7,36>\mathrm{Q}_{\text {tabel }}=4,53$ atau $\mathrm{H}_{0}$ ditoak, maka hasil belajar IPS pada kelompok anak yang belajar dengan teknik pembeajaran Make a match dan gaya kognitif Field Independent lebih rendah daripada kelompok siswa yang diajarkan dengan teknik Think pair share dan gaya kognitif Field Independent. 
Hipotesis keenam, hasil uji tuckey menunjukkan bahwa $Q_{\text {hitung }} A_{I} B_{1}-A_{I} B_{2}=12,86$. Dari tabel dengan $n$ $=8$ dan $\alpha=0,05$ diketahui nilai $Q_{\text {tabel }}=4,53$. Karena $Q_{\text {hitung }} \mathrm{A}_{I} \mathrm{~B}_{\mathrm{I}}-\mathrm{A}_{\mathrm{I}} \mathrm{B}_{2}=12,86>\mathrm{Q}_{\text {tabel }}=4,53$ atau Ho ditolak, maka hasil belajar IPS pada kelompok anak yang belajar dengan teknik pembelajaran Make a match dan gaya kognitif Field Dependent lebih tinggi daripada kelompok siswa yang diajarkan dengan teknik Make a match dan gaya kognitif Field Independent.

Hipotesis ketujuh, hasil uji tuckey menunjukkan bahwa $\mathrm{Q}_{\text {hitung }} \mathrm{A}_{2} \mathrm{~B}_{1}-\mathrm{A}_{2} \mathrm{~B}_{2}=6,73$. Dari tabel dengan $\mathrm{n}$ $=8$ dan $\alpha=0,05$ diketahui nilai $Q_{\text {tabel }}=4,53$. Karena $Q_{\text {hitung }} \mathrm{A}_{2} \mathrm{~B}_{1}-\mathrm{A}_{2} \mathrm{~B}_{2}=6,73>\mathrm{Q}_{\text {tabel }}=4,53$ atau $\mathrm{H}_{0}$ ditolak, maka hasil belajar IPS pada kelompok anak yang belajar dengan teknik pembelajaran Think pair share dan gaya kognitif Field Dependent lebih rendah daripada kelompok siswa yang diajarkan dengan teknik Think pair share dan gaya kognitif Field Independent.

\section{Kesimpulan}

Berdasarkan hasil pengujian hipotesis dan pembahasan dapat disimpulkan sebagai berikut: (I) Hasil belajar IPS siswa yang diberi pembelajaran dengan menggunakan teknik Make a match lebih tinggi daripada kelompok siswa yang diberi pembelajaran dengan menggunakan teknik Think Pair Share, (2) Hasil belajar IPS antara kelompok siswa yang memiliki gaya kognitif Field Dependent lebih tinggi daripada hasil belajar siswa yang memiliki gaya kognitif Field Independent, (3) Terdapat pengaruh interaksi antara metode pembelajaran cooperative (teknik Make a match dan teknik Think Pair Share) dan gaya kognitif terhadap hasil belajar IPS siswa. Artinya pengaruh interaksi antara metode pembelajaran cooperative (teknik Make a match dan teknik Think Pair Share) dengan gaya kognitif berpengaruh terhadap tinggi rendahnya hasil belajar IPS siswa kelas IV Sekolah Dasar, (4) Hasil belajar IPS siswa yang belajar dengan metode pembelajaran cooperative teknik Make a match lebih tinggi dibandingkan dengan siswa yang belajar dengan metode pembelajaran cooperative teknik Think Pair Share yang memiliki gaya kognitif Field Dependent, (5) Hasil belajar IPS siswa yang belajar dengan metode pembelajaran cooperative teknik Make a match lebih rendah dibandingkan dengan siswa yang belajar dengan metode pembelajaran cooperative teknik Think Pair Share yang memiliki gaya kognitif Field Independent, (6) Hasil belajar IPS antara siswa yang mengikuti pembelajaran dengan teknik Make a match yang memiliki gaya kognitif Field Dependent lebih tinggi daripada siswa yang memiliki gaya kognitif Field Independent, (7) Hasil belajar IPS antara siswa yang mengikuti pembelajaran dengan teknik Think Pair Share yang memiliki gaya kognitif Field Independent lebih tinggi daripada siswa yang memiliki gaya kognitif Field Dependent.

Berdasarkan kesimpulan, diajukan beberapa saran yang dapat dipertimbangkan dalam peningkatan kemampuan menulis narasi siswa yaitu: (I) Untuk meningkatkan hasil belajar yang maksimal, disarankan kepada guru untuk menggunakan teknik mind mapping sehingga siswa termotivasi dan senang dalam pembelajaran menulis narasi, (2) Dalam menerapkan teknik mind mapping dan teknik outline melalui drill perlu diperhatikan siswa yang memiliki efikasi diri tinggi dan rendah, sehingga pada proses pembelajaran guru dapat meminimalisir tingkat kekurangan dari masing-masing tingkat efikasi diri siswa yang berimplikasi pada kemampuan menulis narasi siswa,(3)Guru sebaiknya mendapatkan pengalaman dan mengetahui faktor apa saja yang dapat mempengaruhi kemampuan menulis narasi siswa sebelum menginterpretasikannya kedalam pelajaran menulis narasi,(4)Guru yang belum memahami pembelajaran dengan menggunakan teknik mind mapping diharapkan dapat meningkatkan pengetahuannya melalui pelatihan-pelatihan, (5) Bagi peneliti lain disarakan mengadakan penelitian sejenis dengan sampel yang lebih banyak yang terdiri dari beberapa sekolah untuk melihat seberapa besar konstribusi teknik pembelajaran dan efikasi diri siswa terhadap kemampuan menulis narasi.

\section{Referensi}

Brown, H. Douglas. Prinsip Pembelajaran dan Pengajaran Bahasa Edisi Kelima diterjemahkan oleh Noor Cholis dan Yusi Avianto Pareanom. Jakarta: Kedutaan Besar Amerika, 2008. 
Desmita. Psikologi Perkembangan Peserta Didik. Bandung: PT. Remaja Rosdakarya, 2009.

Hamdayama, Jumanta. Model dan Metode Pembelajaran Kreatif dan Berkarakter. Bogor: Ghalia Indonesia, 2014.

Kefee, Jame W. Learning Style Theory and Practice. Virginia: NASSP Association Driven, 1987.

Lie, Anita. Cooperative Learning. Jakarta: PT. Grasindo, 2002

Nurhasanah, Ana. "Peningkatan Hasil Belajar IPS melalui Metode Cooperative Teknik Think Pair Share" Tesis, Universitas Negeri Jakarta, 2012.

Slameto. Belajar dan Faktor-Faktor yang Mempengaruhinya. Jakarta: Rineka Cipta, 2010.

Slavin, Robert E. Cooperative Learning. Bandung : Nusa Media, 2005.

Suprijono, Agus. Cooperative Learning Teori \& Aplikasi PAIKEM. Yogyakarta: Pustaka Pelajar, 2012.

Susanto, Ahmad. Teori Belajar dan Pembelajaran di SD. Jakarta: Kencana, 2013.

Trianto. Model-Model Pembelajaran Inovatif Berorientasi Konstruktivistik. Jakarta: Prestasi Pustaka Publisher, 2007.

Zaitun, Marwah. "Peningkatan Hasil Belajar Pendidikan Kewarganeraan tentang Lembaga-lembaga Negara melalui Metode Cooperative Teknik Make a match" Tesis, Universitas Negeri Jakarta, 201 I.

Zakiah, Aghniyani. "Pengaruh penerapan pendekatan pembelajaran kontekstual (contextual teaching \& learning) Bermedia VCD dan LKS terhadap pencapaian Kompetensi mata pelajaran sejarah ditinjau dari gaya kognitif siswa” Tesis, Universitas Sebelas Maret, 2008. 